\title{
The Effectiveness of The Use of Technology Information in Micro, Small and Medium Enterprises
}

\author{
Riki Aprianto ${ }^{1}$, Rahmat Ilahi ${ }^{2}$, Ryani Dhyan Parashakti ${ }^{3}$ \\ \{rikiaprianto2104@gmail.com ${ }^{1}$, rahmaet212@gmail.com ${ }^{2}$, \\ ryani.dhyan.Parashakti@undira.ac.id ${ }^{3}$ \}
}

\begin{abstract}
Management Department, Faculty of Economy and Business, Universitas Dian Nusantara, West Jakarta, Jakarta, Indonesia ${ }^{1}$, Management Department, Faculty of Economy and Business, Universitas Dian Nusantara, West Jakarta, Jakarta, Indonesia ${ }^{2}$, Management Department, Faculty of Economy and Business, Universitas Dian Nusantara, West Jakarta, Jakarta, Indonesia ${ }^{3}$
\end{abstract}

\begin{abstract}
Abstarct. The low understanding of the digital world by Small Medium Enterprises (SME) in Indonesia is an important point why Small Medium Enterprises (SME) cannot keep up with market developments. As we know that there are many internet users in Indonesia, we can use this for broader marketing. However, the obstacle that is often faced by Small Medium Enterprises (SME) actors is that they do not understand how to take advantage of the Internet, and some have even marketed their products but the results are still ineffective. It is from this problem that we conduct surveys and provide direction and marketing knowledge to Small Medium Enterprises (SME). The activities we carry out also aim to support government programs to advance the Small Medium Enterprises (SME) sector so that they can compete with other competitors, especially during a pandemic like now, there are so many Small Medium Enterprises (SME) that are affected.
\end{abstract}

Keywords: Small Medium Enterprises, Internet, Marketing

\section{Introduction}

The role of SMEs in the Indonesian economy is very significant. Based on data from the Indonesian Central Bureau of Statistics (2006), there are 48.9 million SMEs entering Indonesia and they contribute $99.9 \%$ of the total business [1], this is the main foundation that the MSME sector can survive during the economic crisis caused Covid-19.

The reason is, so far SMEs are Indonesia's economic modality when facing the global economic crisis. The scale of business at the SMEs level not only looks solid in facing the impact of the crisis, but is also capable of survival in such a way in the midst of a global recession. This phenomenon is at least seen both during the global financial crisis of 1997 1998 and the moments of the 2008 - 2009 crisis [2], meaning that the driving factor for economic revival in Indonesia is SMEs, because SMEs are able to absorb far more jobs.

In 2020, Indonesia will again experience an economic crisis caused by the Covid-19 pandemic. Minister of Finance (Menkeu) Sri Mulyani Indrawati said the Covid-19 pandemic not only caused a health crisis but also suppressed the economies of all countries in the world. Even today, there are many countries that have entered into recession due to double digit economic contraction [3], this is a problem for the Indonesian state, where the unemployment 
rate is increasing and state income decreases, because people are having difficulty paying taxes in the midst of this economic crisis.

The role of information technology is an important factor during the current crisis in Indonesia. The number of online shop transactions has increased by 400 percent and is predicted to continue in the new normal, the marketplace platform will get competition from large retailers to minimarkets that also open online services to delivery. "Post and logistics services will compete on the quality of this service," [4]. However, many SMEs have not been able to maximize their market in the digital world, so what happens is that they keep selling even though they have to be evicted by the Satpol PP and other officers. This is a problem in the midst of this pandemic. SMEs do not really understand how to use information technology to increase their sales in the digital world.

Social media is a group of internet-based applications built on the ideological and technological framework of Web 2.0 [5]. Using the internet will facilitate buying and selling transactions because sellers and buyers do not meet face to face directly but only through social media. Digital tools have made product design and manufacturing faster and more efficient than ever before [6]. This means that with information technology, reaching SMEs to expand their market is much easier, and business actors can also get new customers out of town.

Based on the background of the problem above, the following problems can be formulated:

a. How much influence does social media have on the development of Small and Medium Enterprises (SME)?

b. How do you describe the use of social media in Small and Medium Enterprises (SMEs)?

So that the research does not deviate from the problems that have been formulated, the researchers limit the problems studied in this study, while the limitations of the problems in this study are:

a. This research is limited to three types of service businesses, trade and industry and is limited to nine business fields, namely culinary, photography / printing, merchandise, furniture / property, fashion, transportation / automotive, education, beauty and agribusiness.

b. The types of social media used are limited to social media Facebook, WhatsApp, Instagram, Youtube, Google and E-Commerce.

Every research that will be carried out must have a purpose, as well as this research is carried out with several objectives. The objectives of this study are: (a) To see how effective the use of social media is for small and medium enterprises (SME); (b) This is to see how familiar small and medium enterprises (SME) are with social media; (c) To find out the effect on their sales.

Based on the research objectives to be achieved, this research is expected to have benefits. The benefits of this research are as follows: (a) The results of this study are expected to provide added insight and knowledge about the application of social media to develop small and medium enterprises; (b) It is hoped that it will be useful for SME entrepreneurs in the application of social media in developing their business.

\section{Literature Review}

\subsection{Small Medium Enterprises}

In accordance with Law Number 20 of 2008 concerning Micro, Small and Medium Enterprises (MSMEs): (a) Micro Enterprises are productive businesses owned by individuals 
and / or individual business entities that meet the criteria of Micro Enterprises as regulated in this Law. (b) Small Business is a productive economic business that stands alone, which is carried out by an individual or business entity that is not a subsidiary or branch of a company that is owned, controlled, or is a part, either directly or indirectly, of a medium or large business. meets the criteria for Small Business as referred to in this Law. (c) Medium-sized enterprises are productive economic enterprises that are independent, carried out by individuals or business entities that are not subsidiaries or branches of companies owned, controlled, or are part of, either directly or indirectly, with Small or large businesses in the amount net assets or annual sales proceeds as regulated in this Law. (d) SMEs criteria based on total assets and turnover [7].

Micro enterprises are small scale economic activities of the people and are traditional and informal in the sense that they are not registered, have not been registered, and are not yet incorporated. The maximum annual sales proceeds from the business are IDR 100,000,000 and belong to Indonesian citizens [8].

\subsection{Internet}

Internet stands for interconnection networking simple can be interpreted as a global network of computer networks [9]. The Internet is a very large computer network, consisting of millions computer devices connected via a certain protocol for exchange information between the computers. All computers connected on the internet do exchange of information through the same protocol, namely TCP / IP (Transmission Control Protocol / Internet Protocol) (Shahab, 2000). Internet provides access to telecommunication services from information resources to millions of its users spread all over the world [10].

\subsection{Marketing}

Marketing is a social and managerial process in which individuals or groups aim to fulfill their needs and desires through creativity, offering and exchanging product values with others [7]. Marketing as the process by which companies create value for customers and build strong customer relationships in order to capture value from customers in return", which means stating that marketing is a process by which companies create value for customers and build strong customer relationships to capture value from customers. in return [11].

Marketing is one of the activities in a helpful economy in creating that economic value determine the prices of goods and services [9].

\section{Research Methods}

\subsection{Design and research samples}

This research is a descriptive study on Small and Medium Enterprises (UKM) in Jakarta, Bogor, Depok, Tangerang, with a total of 20 respondents. This study uses quantitative methods to examine the effect of independent variables on the dependent variable. The sample selection in the study used a non-probability technique with a convenience sampling method, namely taking samples by taking SMEs who have used social media for marketing tools, such as Facebook, Instagram, Google, Twitter and YouTube.

\subsection{Method of collecting data}

This study used a survey method, the data collection methods obtained directly from the original source through interviews and questionnaire form. The data obtained includes data on general characteristics, data on the use of social media within the company, including the 
objectives, benefits and obstacles faced. The data is complemented by the results of the researchers' observations of the SMEs and social media used.

\subsection{Data Analysis}

Data analysis was performed using quantitative methods, where the data entered through a questionnaire made with the help of Google Forms, will form a diagram and tables that help in the data analysis process.

\section{Results and Discussions}

\subsection{Characteristics and forms of SMEs}

The subjects in this study were owners, managers and employees of SMEs with service, trade or industrial types of business. The areas of business in this research include culinary, photography / printing, merchandise, furniture / property, fashion, transportation / automotive, education, beauty and agribusiness.

Table 1. Characteristics and forms of SMEs

\begin{tabular}{|c|c|c|}
\hline \multicolumn{3}{|c|}{ Type of Business, Line of Business and Long Standing } \\
\hline Type of Business & n (Amount) & Percentage $(\%)$ \\
\hline Service & 4 & $20 \%$ \\
\hline Trade & 15 & $75 \%$ \\
\hline Industry & 1 & $5 \%$ \\
\hline Line of Business & n (Amount) & Percentage $(\%)$ \\
\hline Culinary & 9 & $45 \%$ \\
\hline Photography/Printing & 0 & $0 \%$ \\
\hline Merchandise & 2 & $10 \%$ \\
\hline Property/Furniture & 0 & $0 \%$ \\
\hline Fashion & 6 & $30 \%$ \\
\hline Transportation/Automotive & 0 & $0 \%$ \\
\hline Education & 0 & $0 \%$ \\
\hline Beauty & 3 & $15 \%$ \\
\hline Agribusiness & 0 & $0 \%$ \\
\hline Long Standing & n (Amount) & Percentage (\%) \\
\hline$>1$ Years & 10 & $50 \%$ \\
\hline $2-5$ Years & 7 & $35 \%$ \\
\hline $6-10$ Years & 1 & $5 \%$ \\
\hline$<10$ Years & 2 & $10 \%$ \\
\hline
\end{tabular}

\subsection{Social Media Implementation in SMEs}

All SMEs that are used as objects in this study have implemented social media as a medium for corporate information and communication. Most SMEs use various types of social media to market and advertise company merchandise and services. Nowadays, smartphone apps are important in providing information to other people especially consumer where it can be considered as consumer information systems (CIS) [12]. Almost all SMEs use social media Facebook, WhatsApp and Instagram to display company profiles and company product galleries. Most companies use WhatsApp for company information / communication media and product marketing of the company. In addition, some SMEs also use E-Commerce media to market products and company profiles to the public. E-commerce is a global phenomenon affecting economic and social life throughout the world [13]. Almost all SME have used 
Facebook and Instagram for promotional media. And most SMEs update information on social media every day.

Table 2. Social Media Implementation in SMEs

\begin{tabular}{|c|c|c|}
\hline \multicolumn{3}{|c|}{ Type of Social Media and Features } \\
\hline Facebook & n (Amount) & Percentage $(\%)$ \\
\hline Personal Bio & 18 & $90 \%$ \\
\hline Fanpage & 12 & $60 \%$ \\
\hline Marketplace & 8 & $40 \%$ \\
\hline Facebook Ads & 4 & $20 \%$ \\
\hline \multicolumn{2}{|c|}{ Total Percentage Facebook } & $52,5 \%$ \\
\hline Instagram & n (Amount) & Percentage (\%) \\
\hline Personal Bio & 17 & $85 \%$ \\
\hline Instagram Business & 8 & $40 \%$ \\
\hline Instagram Ads & 3 & $15 \%$ \\
\hline \multicolumn{2}{|c|}{ Total Percentage Instagram } & $46,67 \%$ \\
\hline WhatsApp & n (Amount) & Percentage (\%) \\
\hline WhatsApp Messenger & 7 & $35 \%$ \\
\hline WhatsApp Business & 15 & $75 \%$ \\
\hline \multicolumn{2}{|c|}{ Total Percentage WhatsApp } & $44,5 \%$ \\
\hline Google & n (Amount) & Percentage (\%) \\
\hline Website & 3 & $15 \%$ \\
\hline Google Business & 6 & $30 \%$ \\
\hline Google Ads & 0 & 0 \\
\hline \multicolumn{2}{|c|}{ Total Percentage Google } & $15 \%$ \\
\hline E-Commerce & n (Amount) & Percentage $(\%)$ \\
\hline Tokopedia & 14 & $70 \%$ \\
\hline Lazada & 12 & $60 \%$ \\
\hline OLX & 5 & $25 \%$ \\
\hline Bukalapak & 14 & $70 \%$ \\
\hline Shoppe & 16 & $80 \%$ \\
\hline Zalora & 2 & $10 \%$ \\
\hline Blibli & 2 & $10 \%$ \\
\hline JD ID & 0 & $0 \%$ \\
\hline \multicolumn{2}{|c|}{ Total Percentage E-Commerce } & $40,63 \%$ \\
\hline
\end{tabular}

From the results of the research conducted, it shows that social media Facebook, Instagram, and WhatsApp tend to be preferred because of their ease of sharing information and attracting attention from target markets. Facebook with the like function and the ease of sharing features for sharing information among Facebook users provides a viral effect that can improve product marketing performance, coupled with the ease of interacting with previous comments giving a domino effect to strengthen product image, besides Facebook has many other features that can be utilized by entrepreneurs such as fanpage, marketplace and facebook ads, Facebook is a social networking site that can be used as a place to make friendships with all people around the world to be able to communicate with one another [14]. Instagram is a social network that offers its users the opportunity to share their lives through a series of pictures [15]. Instagram, with the ease of posting a visual display in the form of still images and short videos, will make the products that are uploaded most often have a higher tendency to attract the attention of consumers, Instagram also has a business Instagram feature where entrepreneurs can evaluate the market appropriately and correctly even with traffic. It's free, Instagram also has paid ads or advertising facilities, with Instagram ads making the marketing term even wider. WhatsApp Messenger itself is a chat application in the form of Mobile 
Instant Messaging (MIM) that provides text, images, location, video, and audio messaging services as well as video and audio calls using smartphones based on Android, Blackberry, iOS, Symbian (s60), and Windows Phone [16], in its development WhatsApp launched a new feature in the form of WhatsApp Business, whatsapp is specifically for entrepreneurs who wants to sell his product more accurately. Google is a search engine that has extraordinary features, there are many facilities offered by Google, such as Google Business, Google Maps and Google Ads. The Google search engine took more factors into account than any other search engine on the market [17], but Indonesian SMEs have not been able to maximize the benefits of Google. E-Commerce is a place of buying and selling that is starting to be dominated by most SMEs, there are many types of e-commerce in Indonesia, but only a few people know, with the help of e-commerce, SMEs can easily sell their products, besides sellers and buyers do not need to be afraid of fraud, because everything has been monitored by the e-commerce party itself.

Other types of social media that have the potential and can also be used as corporate marketing communications but which have not been used by the object of this research include Google+, LinkedIn, Pinterest, Tumblr, MySpace [18].

\subsection{Effectiveness of Use of Information Technology}

The results of the above research show that the results are less effective with an average percentage below 50\%. From these results, SMEs in Indonesia have not fully utilized information technology as an effective marketing medium. Lack of understanding of techniques in marketing such as copywriting, storytelling and closing techniques makes advertisements posted less effective, not only that there are many SMEs who don't know what paid traffic is such as Facebook Ads, Instagram Ads, Google Ads, and those that currently exist TikTok Ads, TikTok - known as DouYin in China - is a social media application used for creating and sharing short videos [19]. SMEs themselves are not sufficiently skilled in marketing so that sometimes they feel that their advertisement is wrong or that they are selling the wrong product. This is of course a serious concern for the government so that it can improve the skills of SMEs in the IT field. Based on the data we obtained from 20 respondents regarding the effectiveness of the role of social media with information on point $1=$ very ineffective, point $2=$ ineffective, point $3=$ quite effective, point $4=$ effective, and point $5=$ very effective.

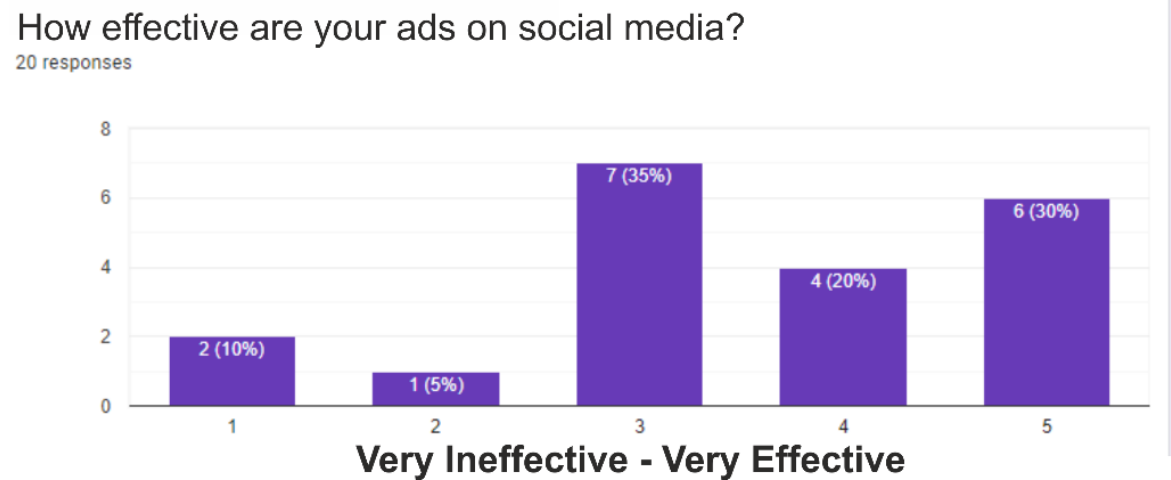

Figure 1. Effectiveness of Use of Information Technology

This study shows the number of respondents with the level of effectiveness of using social media for the products of each UKM. There are 2 people who feel that social media has 
no effect at all, 1 person feels ineffective, 7 people feel quite effective, 4 people are already effective and only 6 people with a percentage of $30 \%$ who are very effective, and even then only with free traffic. This is the basis for SMEs to continue to improve their skills in the world of marketing, both with free and paid traffic.

Business growth is a measure of a company's success, and success is a benchmark for investments that will be made in the future, customers can be satisfied with the benefits [20]. The progress of Indonesian SMEs is progress for the nation, with the increase in knowledge for business actors, it will certainly be the main foundation for a country to dominate the world market.

\section{Conclussions and Suggestions}

Although Information Technology has been believed to provide great benefits to companies, in reality, there are still few SMEs, especially in developing countries, that use Information Technology. In fact, among SMEs that use Information Technology, most are still experiencing difficulties in implementation or the technology implemented does not provide positive benefits to the company.

Given that in this era of globalization, the arena of competition is increasingly competitive, mastery of information technology is a must. To support and increase the effectiveness of the use of information technology in SMEs, perhaps the government or related agencies could make a training or education program related to how to use information technology to increase the marketing of SME products. If everything is carried out well, it is not impossible that the competitiveness of SME products can be better.

\section{Acknowledgements}

Acknowledgements. Thank you to SME players who have been willing to be a sample of this research, and we would like to thank all ICETOBE committee members for their trust in us to participate in this paper. Hopefully this paper can be useful and become the next reference material for learning for students, lecturers or public actors.

\section{References}

[1] D. Sari and N. Beaumont, "Internationalisation of Small Medium Sized Enterprises in Indonesia: Entrepreneur Human and Social Capital," no. July, pp. 1-12, 2008.

[2] Portal Informasi Indonesia, "Learn from the Experience of Facing the World Economic Crisis," Indonesia.go.id, 2019. .

[3] L. J. Sembiring, "Sri Mulyani Updates About the Economic Crisis Due to Corona, Listen!," CNBC Indonesia, 2020. .

[4] Gusti, "Online Sales Transactions Up 400 Percent during the Covid-19 Pandemic," ugm.ac.id, 2020. .

[5] A. M. Kaplan and M. Haenlein, "Users of the world, unite! The challenges and opportunities of Social Media," Bus. Horiz., vol. 53, no. 1, pp. 59-68, 2010, doi: 10.1016/j.bushor.2009.09.003.

[6] A. Westerman, George, Bonnet, Didier, McAfeee, Le ding Digital. 2014.

[7] M. Kristiyanti and L. Rahmasari, "Website as a Marketing Media for Leading MSME Products in 
Semarang City," vol. 186, 2015.

[8] B. A. B. Ii, A. U. Mikro, and P. U. Mikro, "TulusTambunan, Small Medium Enterprises in Indonesia (Important Issue) , Jakarta: LP3ES, 2012, h. 1214 18,” pp. 18-42, 2008.

[9] I. Elissa, "To E-Commerce," vol. VIII, no. 3, pp. 143-152.

[10] R. Setiyani, "Utilization of the internet as a learning resource," vol. V, no. 2, pp. 117-133, 2010.

[11] B. A. B. Ii and T. Pustaka, Literature Review. Universitas Islam Bandung, 2012.

[12] J. Ibrahim, R. C. Ros, N. F. Sulaiman, R. C. Nordin, and L. Ze, "Positive Impact of Smartphone Application: Whatsapp \& Facebook for Online Business,” vol. 4, no. 12, pp. 1-4, 2014.

[13] K. C. Laudon, E-commerce.

[14] K. A. Akhmad, "Pemanfaatan Media Sosial bagi Pengembangan Pemasaran UMKM (Studi Deskriptif Kualitatif pada Distro di Kota Surakarta)," Duta.com, vol. 9, no. September, pp. 43-54, 2015, doi: 2086-9436.

[15] T. Bergström and L. Bäckman, "Marketing and PR in Social Media: How the utilization of Instagram builds and maintains customer relationships," Media Commun., p. 56, 2013.

[16] K. A. Prihatna, R. Ayal, M. Sistarani, and Y. Christanti, "What Whatsapp status enables reseller to do as channel,” Int. J. Innov. Technol. Explor. Eng., vol. 8, no. 9 Special Issue 3, pp. 44-55, 2019, doi: 10.35940/ijitee.I3009.0789S319.

[17] D. Vise, “The Google Story," Strateg. Dir., vol. 23, no. 10, pp. 117-133, 2007, doi: 10.1108/sd.2007.05623jae.001.

[18] M. H. Purwidiantoro, D. F. Kristanto, and W. Hadi, "Pengaruh Penggunaan Media Sosial Terhadap Pengembangan Usaha Kecil Menengah (UKM)," Maret, vol. 1, no. 1, pp. 30-39, 2016.

[19] I. Knowledge, "The TikTok Strategy: Using AI Platforms to Take Over the World," pp. 1-2, 2019.

[20] N. R. Baptiste, "Tightening the link between employee wellbeing at work and performance: A new dimension for HRM," Manag. Decis., vol. 46, no. 2, pp. 284-309, 2008, doi: $10.1108 / 00251740810854168$. 